Abstracta Iranica

Revue bibliographique pour le domaine irano-aryen

Volume 34-35-36 | 2017

Comptes rendus des publications de 2011-2013

\title{
Grant Frame, Caroline Waerzeggers. The Prebend of Temple Scribe in First Millennium Babylonia
}

\section{Astrid Nunn}

\section{OpenEdition}

1 Journals

\section{Édition électronique}

URL : http://journals.openedition.org/abstractairanica/41437

DOI : 10.4000/abstractairanica.41437

ISSN : 1961-960X

Éditeur :

CNRS (UMR 7528 Mondes iraniens et indiens), Éditions de l'IFRI

\section{Référence électronique}

Astrid Nunn, «Grant Frame, Caroline Waerzeggers. The Prebend of Temple Scribe in First Millennium Babylonia », Abstracta Iranica [En ligne], Volume 34-35-36 | 2017, document 9, mis en ligne le 15 juillet 2016, consulté le 05 octobre 2020. URL : http://journals.openedition.org/abstractairanica/41437 ; DOI : https://doi.org/10.4000/abstractairanica.41437

Ce document a été généré automatiquement le 5 octobre 2020.

Tous droits réservés 


\title{
Grant Frame, Caroline Waerzeggers. The Prebend of Temple Scribe in First Millennium Babylonia
}

\author{
Astrid Nunn
}

\section{RÉFÉRENCE}

Grant Frame, Caroline Waerzeggers. « The Prebend of Temple Scribe in First Millennium Babylonia ». ZA, 101, 2011, p. 127-151.

1 Le système de prébende était très répandu en Babylonie au Ir mill. av. J.-C. Très rares sont cependant les documents qui prouvent l'existence de prébende pour un scribe. Les deux documents présentés dans cet article éclairent la situation d'un scribe travaillant pour un temple dans la Babylonie du VII ${ }^{e}$ s. av. J.-C. Il semble que le système de prébende continua à être possible pour les scribes jusqu'à l'époque achéménide.

\section{AUTEURS}

\section{ASTRID NUNN}

Université de Munich 